Jurnal ASPIKOM, Vol. 7, No. 1, January 2022, pp. 1-15

P-ISSN: 2087-0442, E-ISSN: 2548-8309

DOI: http://dx.doi.org/10.24329/aspikom.v7i1.1013

\title{
How the Print Media Industry Survived in the Digital Era
}

\author{
Firmansyah*, Sophia Novita, Atie Rachmiatie, Septiawan Santana K., Alex Sobur, \\ Dian Widya Putri \\ Universitas Islam Bandung, Jawa Barat, Indonesia \\ *Corresponding author, e-mail: fimansyah.ivan272@gmail.com
}

\begin{abstract}
In the era of information technology, print media is on the verge of extinction. The Pikiran Rakyat Newspaper, one of the largest local newspapers in West Java, still survives. This study illustrates how print media can survive in the era of digital society. This research uses a sequential explanatory design method by combining quantitative and qualitative data. Quantitative data was collected using a survey to a sample of readers totaling 1540 respondents. The sample was determined using purposive sampling with unique qualifications for potential readers in West Java. Qualitative data using observation, interviews, and FGD. The quantitative results showed that respondents admitted they were still interested in consuming newspapers. Newspapers have advantages over online media; clickbait does not exist. The qualitative results indicate that print media can still survive, not as a source of income but as an icon of the company.
\end{abstract}

Keywords: Digital Era; Industry; Newspaper; Pikiran Rakyat; Print Media

\begin{abstract}
Abstrak
Di era teknologi informasi, media cetak di ujung kepunahan. Surat Kabar Pikiran Rakyat, salah satu media cetak lokal terbesar di Jawa Barat masih bertahan. Penelitian ini menggambarkan bagaimana media cetak dapat bertahan di era masyarakat digital. Penelitian menggunakan metode sequential explanatory design, dengan menggabungkan data kuantitatif dan kualitatif. Pengumpulan data kuantitatif menggunakan survei kepada sampel pembaca berjumlah 1540 responden. Penentuan sampel dengan teknik sampling purposive sampling dengan kualifikasi khusus pada pembaca potensial di Jawa Barat. Data kualitatif menggunakan observasi, wawancara, dan FGD. Hasil data kuantitatif menunjukkan bahwa sebagian responden mengaku masih berminat mengonsumsi surat kabar. Surat kabar memiliki kelebihan dibandingkan media online yakni tidak click bait dan lebih teruji faktanya. Hasil kualitatif menunjukkan bahwa eksistensi media cetak masih dapat bertahan, namun bukan sebagai sumber pemasukan tetapi sebagai ikon perusahaan.
\end{abstract}

Kata Kunci: Era Digital; Industri; Koran; Pikiran Rakyat; Media Cetak 


\section{Introduction}

Print media is a form of mass communication that dominates various histories and civilizations. Mass communication in print media has distinctive characteristics. Indonesian print media is still in the stage of adopting media convergence. Print media are trying to improve the content without thinking about a business development strategy (Saragih \& Harahap, 2020). The print media industry has experienced a decline due to technological developments that have forced print media to switch to online formats (McKenney, 2018). This is inseparable from changes in reader consumption patterns due to communication and information technology (Aminuddin \& Hasfi, 2020; Hasni et al., 2019). Along with the dynamics and challenges that develop in the press and print media industries, media convergence and its integration between print, electronic and online are the best choices to survive in the world of the press industry with the harmony of strengthening its resources (Nurliah, 2018; Restendy, 2020).

The difference between digital and classical media devices is that digital media is created, modified, and distributed on digital devices (Karambelkar, 2019). However, in online media, the facts are increasingly obscured by the existence of false information that is spread with the help of technology (Othman et al., 2020). Print media has an advantage in terms of deepening news. Its characteristic that is different from other media types is the completeness in presenting facts in the news (Kurnia et al., 2021). To survive, conventional media must maintain credibility and trust in the information presented. This credibility and public trust can only be built by the professional spirit of journalists who adhere to journalism ethics, namely presenting factual and well-verified information (Kusuma, 2016; Firmansyah \& Asgha, 2020). However, not only credibility, print media need other strategies to retain their readers. Information consumption patterns in society will also determine how the media can survive. Without the audience as consumers, the print media will find it difficult to survive amid changes in society in consuming news.

The newspaper's main income comes from advertising. It is always difficult for advertisers to distinguish between the core readers of a particular newspaper and the circulation figures it publishes, which makes aiming difficult. So newspapers need to adapt to the development of digital technology (Doyle, 2015). In the digital information age, many newspapers are required to make copies for the online version (Smits, 2014). The media and publishing industry is undergoing a significant transformation thanks to the advent of digital, which has made traditional subscription-only revenue models and ad sales virtually obsolete (Vidas-Bubanja \& Bubanja, 2015). Print media is starting to be threatened. Loyal readers of print media are likely to switch to online media. This reality does threaten print media publishers, but print media has a distinctive character, namely: clear, complete, and detailed news, besides that, for centuries, print media has accompanied the development of human civilization, so it is not easily forgotten (Kusuma, 2016).

Several studies indicate young people who do not like reading news activities. This is because young people prefer information from social media. However, social media contains much information that is not based on facts and contains false information (Marchi, 2012) (Rampersad \& Althiyabi, 2020). Research by the Pew Research Center (2012) shows that only 29\% of Millennials (ages 18-34) really enjoy following the news. Meanwhile, the X generation (aged 35-55) amounted to 45\%.

Moreover, as much as 58\% are the Silent Generation and Baby Boomers. (Zickuhr $\&$ Madden, 2012). Media consumption patterns have changed a lot, from news 
consumption to digital information consumption (Subudhi, 2021). So this study aims to reveal how print media can survive in the era of digital society. Changes in people's consumption patterns have resulted in the questionable existence of print media. Can print media survive, or will it become extinct over time?

The Pikiran Rakyat Newspaper is a print media with a long history and one of Indonesia's largest print media with cultural identity (Dewi, 2011). Since 1950, the Pikiran Rakyat newspaper has become a forum for people's aspirations, especially in West Jawa, Indonesia. For decades, the Pikiran Rakyat Newspaper has become a motor in democratic thoughts and public spaces (Tim Pikiran Rakyat, 2019). However, the development of the digital technology era has made many print media now have a difficult time surviving (Leksmana et al., 2020) (Supadiyanto, 2020), including the Pikiran Rakyat Newspaper. Until now, the Pikiran Rakyat newspaper is still published, but only for subscribers. Retail sales have been closed and production has even decreased considerably. However, the Pikiran Rakyat newspaper has persisted to this day with various strategies. In the theory of political media economy, the press industry cannot survive if it has lost its customers (Albarran, 1998). Pikiran Rakyat Newspaper has tried to adapt by launching various forms and formats of print media (McQuail, 2010) including electronic newspapers or e-papers which are offered online and do not have time and location restrictions as traditional newspapers. But in the end, production costs cannot cover operational costs. In the economic principle in the media industry, it is necessary to have a healthy balance sheet where the income from the sale of newspapers or advertising must be greater than the cost of production (Picard, 2003).

Newspapers, like the industry in general, depend on market needs. If the market has changed, then the industry is already difficult to save. Pikiran Rakyat Newspaper must follow the market's wishes, including news (Altınba, 2016). In an industry, media consumers can demand content containing educational information, not just advertising and entertainment, by buying or refusing to buy. They can insist that the mass media meet their need for information that is prepared objectively and professionally. So the question of how print media can survive in the era of digital society is very important to be investigated further.

\section{Method}

This study uses a combination of Sequential Explanatory Design models. The research method is a combination of sequential explanatory model, characterized by data collection and quantitative data analysis in the first stage, followed by qualitative data collection and analysis in the second stage, to strengthen quantitative research results conducted in the first stage (Creswell, 2009). This model is called the sequence of the proof model because after there is evidence, the following sequence is deepened through focus group discussions, observations, and interviews.

The research conducted data collection by collecting 1540 respondents. The determination of the sample is carried out using a purposive sampling technique, based on the premise that seeking out the best cases for the study produces the best data, and research results are a direct result of the cases sampled (Leavy, 2017). The sample is people who live in the West Java region who are potential readers of the Pikiran Rakyat Newspaper. Regional restrictions are based on consideration of the segmentation of the audience in the West Java region.

While the qualitative data, the research conducted data collection techniques Focus Group Discussion and in-depth interviews (Creswell, 2013). Collecting 
qualitative data in the field, it is necessary to determine active informants, have insight, feelings, and cooperation related to the topic of a process discussion process to reveal subjective meanings (Djamba \& Neuman, 2002). The selection of informants was based on categories in the representation of community leaders consisting of regional figures, observers, or those who had a functional and emotional closeness to the Pikiran Rakyat newspaper. The informant is also an active reader and has subscribed to the newspaper for more than 20 years. Meanwhile, in-depth interviews were conducted with the Pikiran Rakyat newspaper involved in the editorial and coverage to understand the business strategy and news production in the Pikiran Rakyat newspaper. The analysis of this research uses descriptive evaluative research, namely the research findings are analyzed again with the concepts and theories used, namely those related to journalism, newspaper management, the media industry, also touching the shift in business models in the media industry.

\section{Results and Discussion}

Print media is one of the mass media capable of attracting the audience's attention simultaneously. Characteristics of print media can be documented, reviewed, compiled for the benefit of knowledge, and used as authentic evidence of high value. A media company, especially local print media, needs to maintain its existence in the world of presenting good, balanced, and impartial information (Fazryansyah et al., 2014). Local print media such as the Pikiran Rakyat Newspaper needs to have a thorough study in implementing a strategy to maintain a press company, both in news production and industrial economic aspects. This study seeks to uncover problems, evaluations, and strategies that can be used for print media, especially newspapers, in the era of digital information consumer society. This study seeks to uncover problems from all aspects, both from the audience of potential readers through quantitative data and from the views of experts and editors of the Pikiran Rakyat newspaper through qualitative data. Quantitative data is carried out by survey with the following data.

\section{Respondent Data}

The survey was conducted on a purposive sample of potential readers of the Pikiran Rakyat Newspaper totaling 1,540 respondents from West Java. The survey uses questionnaire data in the form of an online form that is distributed randomly to people who have read the Pikiran Rakyat Newspaper. Based on the data collected, more than 97.5\% of respondents who filled out the questionnaire stated that they knew and had read the Pikiran Rakyat Newspaper. So assuming a margin of error of $2.5 \%$, respondents who fill out the questionnaire are considered to have met the requirements as a sample of the potential reader preference survey. Based on this, the questionnaire data can be used as a description of the West Java community's audience for the Pikiran Rakyat newspaper.

The sample of the survey is the public who have experience of reading or have read the printed media of the Pikiran Rakyat Newspaper. The sample selection was based on the consideration that the survey could accommodate every aspiration of the audience in the West Java area. Based on the data, 1,540 respondents based on gender were divided into $68.4 \%$ men and $31.6 \%$ women. Respondents who filled out the questionnaire were dominated by men, but not much different.

Respondents from the age group 24-37 years (40.7 percent) and ages 38-56 years (40.3 percent) were the most respondents who filled out the questionnaire. When 
viewed from the location of the respondents, it can be seen that as many as $83.5 \%$ of respondents live in the Greater Bandung area. Respondents are located in four geographic areas in West Jawa, Indonesia, with categories in each area of distributing the questionnaire, namely in the category of Greater Bandung, East Priangan, Ciayumajakuning, and other West Java regions such as Bogor, Sukabumi, Depok, Bekasi, Cianjur, and others. This categorization is based on the categorization of Pikiran Rakyat Newspaper print media sales, with the most respondents coming from the Greater Bandung area, which is the main area for selling Pikiran Rakyat Newspaper.

Regarding the social status of work, respondents who filled out the questionnaire came from various professions and occupations. However, based on the results, most of the respondents were from private employees, civil servants, and entrepreneurs, with a combined total of 55.7\%. From academics (both lecturers/teachers and students), as much as $24.8 \%$. Meanwhile, the other $19.5 \%$ come from various social statuses such as housewives and freelancers to online motorcycle taxi jobs. This diversity of occupations and professions enriches the views of the sample audience in West Jawa.

\section{Newspaper Consumption Behavior on Respondents}

The public's interest and consumption of newspapers is a concern. So the question of interest and consumption for reading newspapers needs to be explored. In the following, a discussion of the respondent's behavior towards the Pikiran Rakyat Newspaper will be explained. Broadly speaking, the questions asked will discuss the intensity of respondents when reading newspapers, the media used by respondents to read newspapers, and how respondents get newspapers (Table 1).

Table 1. Respondents' Behavior towards Newspaper Consumption

\begin{tabular}{clcc}
\hline No & \multicolumn{1}{c}{ Type of Questions } & $\begin{array}{c}\text { Total } \\
(\mathbf{n = 1 5 4 0 )}\end{array}$ & $\begin{array}{c}\text { Percentage } \\
(\mathbf{\%})\end{array}$ \\
\hline 1 & Newspaper Reading Frequency & & \\
& Always & 491 & 31,9 \\
& Sometimes & 971 & 63,0 \\
& Other & 78 & 5,1 \\
\hline 2 & Newspaper Reading Accessibility & & \\
& Electronic newspaper (epaper) & 446 & 29,1 \\
& Printed newspaper & 271 & 17,7 \\
& Electronic (e-paper) and print newspapers & 818 & 53,2 \\
\hline 3 & How to get newspapers & & \\
& Subscribe & 344 & 22,3 \\
& Buy retail & 877 & 57 \\
& Other & 319 & 20,7 \\
\hline
\end{tabular}

Based on the questionnaire results, the majority of respondents consume newspapers through print media and electronic newspapers (e-paper) with a total of $63 \%$. Meanwhile, respondents who consume electronic newspapers only $10 \%$ more than print newspapers. Other data shows that more than 50 percent of respondents obtain newspapers by buying retail, while more than 18 percent do not buy or subscribe. This shows that not many people choose to subscribe to newspapers, with the percentage only reaching 23 percent. Buying retail is the most preferred choice of respondents in obtaining newspapers. This shows that the consumption of newspapers has greatly 
decreased in the community, and the tendency of respondents to have more free information and less premium information that is subscribed to.

\section{Respondents Interest in Newspaper}

In the era of information technology development, audiences are more active in looking for news according to their wishes and things that they find interesting. Personal experience, knowledge, and media habits followed by good media literacy affect the reader's meaning (Purnamasari, 2018). So the research needs to also look at the picture of the interest in reading newspapers to find out the habits of consuming information on respondents related to newspaper consumption. The description of respondents' views on news consumption can be seen in table 2 .

Table 2. Respondents' Opinion on News Consumption

\begin{tabular}{|c|c|c|c|}
\hline No & Type of Questions & $\begin{array}{c}\text { Total } \\
(n=1540)\end{array}$ & $\begin{array}{c}\text { Percentage } \\
(\%)\end{array}$ \\
\hline \multirow[t]{9}{*}{1} & Source of Consumption of News and Information & & \\
\hline & Daily Newspaper & 926 & 60,1 \\
\hline & Weekly Tabloid & 137 & 8,0 \\
\hline & Monthly Magazine & 77 & 5 \\
\hline & Online News & 1048 & 68,1 \\
\hline & Social media & 905 & 58,9 \\
\hline & Radio & 297 & 19,3 \\
\hline & Television & 515 & 33,4 \\
\hline & Other & 21 & 1,4 \\
\hline \multirow[t]{6}{*}{2} & Types of Print Media Still Consumed & & \\
\hline & Daily Newspaper & 1118 & 72,6 \\
\hline & Tabloids & 250 & 16,2 \\
\hline & magazine & 337 & 21,9 \\
\hline & Book & 633 & 41,1 \\
\hline & Other & 45 & 2,9 \\
\hline \multirow[t]{8}{*}{3} & Benefits of Consuming Print Media & & \\
\hline & Love the content and news & 737 & 47,9 \\
\hline & Subscribe long ago & 709 & 46,0 \\
\hline & Can be documented & 459 & 29,8 \\
\hline & Cheap price & 368 & 23,9 \\
\hline & Interesting & 362 & 23,5 \\
\hline & Comfortable reading & 285 & 18,5 \\
\hline & Other & 103 & 6,7 \\
\hline \multirow[t]{6}{*}{4} & Advantages of Print Media Compared to Online Media & & \\
\hline & More depth & 652 & 42,3 \\
\hline & Proven fact & 694 & 45,0 \\
\hline & Easy to archive & 505 & 32,8 \\
\hline & No clickbait (not bombastic/sensational) & 761 & 49,4 \\
\hline & Other & 68 & 4,4 \\
\hline \multirow[t]{5}{*}{5} & Reasons for Consuming Print Media in the Digital Age & & \\
\hline & Had become a habit & 941 & 61,1 \\
\hline & Lack of understanding of online media access (online) & 738 & 47,9 \\
\hline & There is emotional closeness & 34 & 2,28 \\
\hline & Other & 220 & 14,3 \\
\hline
\end{tabular}

6 Reasons for Rarely Consuming News and Information 


$\begin{array}{lll}\text { The price (not free) } & 361 & 23,4 \\ \text { Less practical } & 690 & 44,8 \\ \text { It doesn't look attractive } & 493 & 32,0 \\ \text { Not interesting news } & 215 & 14,0 \\ \text { It's outdated } & 304 & 19,7 \\ \text { Other } & 191 & 12,4\end{array}$

Based on the results of the table above, it can be seen that the most preferred source of respondents when consuming information and news is an online news, followed by daily newspapers and social media. Then, when the media used is printbased media, daily newspapers are the most used by respondents when reading the news, with the most chosen reason being their liking for the content and the way the news is delivered. Then, according to the respondents, the most perceived advantage when reading news through newspapers is that it is not clickbait (not bombastic/sensational). Then, most respondents put forward so that they still access news through print media until now because it has become a habit. However, along with the times, the reduced interest of readers to read news through newspapers is common, with the biggest reason being the lack of practical sense felt by respondents.

From the survey results, respondents stated that newspapers have a number of advantages, namely, not clickbait (49.4\%), proven facts $(45.1 \%)$, and more in-depth (42.3\%). The survey also shows that respondents began to leave newspapers for various reasons; namely, it is not practical $(44.8 \%)$, less attractive $(32 \%)$, not free $(23.4 \%)$, outdated $(19.7 \%)$, and less interesting news (14\%).

However, what is exciting and needs to be observed is why respondents still consume newspapers until now, dominated by two choices: itt has become a habit $(61.1 \%)$ and emotional closeness (47.9\%). This shows that two aspects of habit (culture) and emotional closeness are why respondents still consume print media. Even so, changes in information consumption patterns in the digital era have made print media remain abandoned. This can be seen based on $46.5 \%$ of respondents preferring issues/topics that are being discussed on social media. At the same time, the special issues on the editorial agenda and case investigations are only about $20 \%$ of the respondents who voted. In a geographic context, the majority of respondents chose news with a national scope (37\%), local news (29.5\%), and regional news $(23.3 \%)$. This shows that national issues are still a public concern. However, when combined, local and regional news exceeds the percentage of national news. Based on the survey, the West Java rubric $(62.1 \%)$ became the respondent's choice to continue to be developed at Pikiran Rakyat Newspaper, followed by the technology (42.9\%) and education $(41.4 \%)$.

\section{Focus Group Discussion}

Qualitative data can complement quantitative data, which is descriptive and does not lead to a solution. So to find the continuity of the research, qualitative data were taken from focus group discussions (FGDs) which contained opinions from community leaders who have close ties to the Pikiran Rakyat Newspaper, both as readers, writers, and even customers. Community leaders are divided into several elements, namely feminist figures, political figures, economic figures, education leaders, communication leaders, cultural leaders, youth leaders, press councils, technocrats, west java provincial government, west java broadcasting commission, and academics. The results of FGD coding can be seen in Table 3 . 
Table 3. Summary of FGD Informants' Statements

\begin{tabular}{|c|c|c|c|}
\hline No. & Informant & $\begin{array}{l}\text { Type of Public } \\
\text { Figure }\end{array}$ & Statements \\
\hline 1. & $\begin{array}{l}\text { Popong } \\
\text { Otje Djundunan }\end{array}$ & Feminist Figures & $\begin{array}{l}\text { Maintain characteristics and strong } \\
\text { emotional ties with the people of West Java }\end{array}$ \\
\hline 2. & $\begin{array}{l}\text { Tjetje Hidayat } \\
\text { Padmadinata }\end{array}$ & Political Figure & $\begin{array}{l}\text { Pikiran Rakyat pay less attention to regional } \\
\text { ideologies and should return to the } \\
\text { characteristics of West Java }\end{array}$ \\
\hline 3 & $\begin{array}{l}\text { Prof. Deddy } \\
\text { Mulyana, M.A., } \\
\text { Ph.D }\end{array}$ & Academics & $\begin{array}{l}\text { Need the right blueprint or grand design. } \\
\text { Print media will never lose customers as } \\
\text { long as they are concerned with education. }\end{array}$ \\
\hline 4 & $\begin{array}{l}\text { Acuviarta } \\
\text { Kartabi, SE., } \\
\text { ME. }\end{array}$ & Economic figures & $\begin{array}{l}\text { From a business perspective, Pikiran Rakyat } \\
\text { Newspaper requires a balance of content } \\
\text { and consistency of reporting. The } \\
\text { superiority of the Pikiran Rakyat } \\
\text { Newspaper has a great historical aspect, } \\
\text { which is the icon of West Java news }\end{array}$ \\
\hline 5 & $\begin{array}{l}\text { Prof.Dr.Ir. } \\
\text { Ganjar Kurnia, } \\
\text { DEA. }\end{array}$ & Education figure & $\begin{array}{l}\text { Readers of Pikiran Rakyat Newspaper on } \\
\text { the demographic aspect, only to the elderly. } \\
\text { Millennials seem to be a lot of people who } \\
\text { don't read }\end{array}$ \\
\hline 6 & $\begin{array}{l}\text { Prof. Dr. Karim } \\
\text { Suryadi, M.Si }\end{array}$ & $\begin{array}{l}\text { Communication } \\
\text { Figure }\end{array}$ & $\begin{array}{l}\text { Readers of the Pikiran Rakyat Newspaper } \\
\text { on the demographic aspect, only to the } \\
\text { elderly. Millennials seem to be a lot of } \\
\text { people who don't read }\end{array}$ \\
\hline 7 & $\begin{array}{l}\text { Dr. Wawan } \\
\text { Hawe Setiawan, } \\
\text { M.Sn. }\end{array}$ & Cultural Figure & $\begin{array}{l}\text { The style of the Pikiran Rakyat Newspaper } \\
\text { tends to escape its characteristics. }\end{array}$ \\
\hline 8 & $\begin{array}{l}\text { Waseso } \\
\text { Wibisono }\end{array}$ & Youth leaders & $\begin{array}{l}\text { Viral information which means it spreads } \\
\text { like a virus, is certainly not good to follow. } \\
\text { There needs to be a strong foundation to } \\
\text { counterattack the current situation }\end{array}$ \\
\hline 9 & $\begin{array}{l}\text { Muhammad } \\
\text { Ridlo Eisy }\end{array}$ & Press Council & $\begin{array}{l}\text { Not infrequently when reading a digital } \\
\text { newspaper, the application does not open. } \\
\text { So when digital products are present, their } \\
\text { presence can meet the needs of today's } \\
\text { millennials, at least with easy access. }\end{array}$ \\
\hline 10 & Arfi Rafnialdi & Technocrat & $\begin{array}{l}\text { Pikiran Rakyat Newspaper must be able to } \\
\text { be present as a medium that provides } \\
\text { solutions for displaying information without } \\
\text { hoaxes that are spread across various media }\end{array}$ \\
\hline 11 & Fajar & $\begin{array}{l}\text { West Java } \\
\text { Government }\end{array}$ & $\begin{array}{l}\text { Pikiran Rakyat Newspaper emphasize } \\
\text { interesting and easy-to-read information. In } \\
\text { this case, it can use infographics and also } \\
\text { provides a forum for the community to } \\
\text { display the community page }\end{array}$ \\
\hline 12 & Roni Tabroni & $\begin{array}{l}\text { West Java } \\
\text { Broadcasting } \\
\text { Commission }\end{array}$ & $\begin{array}{l}\text { Print context should not dissolve and should } \\
\text { not lost his trust. There is a very strict } \\
\text { tradition of journalism. The government } \\
\text { must make a media business model policy }\end{array}$ \\
\hline
\end{tabular}


Based on the results of the FGD, all of the informants hoped that the Pikiran Rakyat Newspaper would still exist by maintaining its distinctive feature, namely the "face" of West Java remains dominant because there is an emotional connection that has traditionally existed between Pikiran Rakyat Newspaper and the people of West Java. The Pikiran Rakyat Newspaper has historical value in West Java. It has become an "icon" of pride for West Java intellectuals/figures as an arena for the "public sphere" of ideas and ideas. Some informants believe that print media will not disappear as long as there are more and more educated people. Print media can still exist and become a quality, in-depth, comprehensive, and trustworthy alternative media. Even though print media is far behind in speed compared to online media or social media, it is seen from the quality of information that it is superior. Concerns as a nation, Indonesia will lose the tradition of reading literacy that is serious, systematic, in-depth, comprehensive, and complete, which is a requirement to build civilization and develop science and technology. The character of the information is in print media, including books and newspapers.

\section{Journalism Challenges in Print Media}

Print media is faced with the reality of extinction. Online media and social media are shifting print media as a source of information, although the level of trust is not as high as print media. The Pikiran Rakyat newspaper has implemented various strategies to save operations. However, it is tough to survive in the era of digital society that prefers the speed and convenience offered by online media. In the midst of competition with online media, the emergence of social media has further exacerbated the positioning of the print media industry in the information market. As a result, the Pikiran Rakyat Newspaper makes print production efficient. The Editorial Board of the Pikiran Rakyat Newspaper, Erwin Kustiman, revealed that newspapers automatically reduce their number of print productions because the production costs are very high. "..the actual natural fiber is still at 65 thousand to 100 thousand, but then because the production cost is high, the homework is deliberately reduced to 20-30 thousand because production costs for purchasing paper raw materials can no longer be met," he said covered by advertisements..."

Pikiran Rakyat Newspaper tried to implement the strategy by changing the news's format, appearance, and presentation. However, Erwin explained that as an entrepreneur, the owner wanted (Pikiran Rakyat Newspaper) to be closed because of the high cost of production and unbalanced economic principles. "...in the present condition, we are at 12 pages, Qualitatively, the public (readers) are very welcome with more attractive, colorful graphics, but management is pressing so that the circulation does not reach 20-30 thousand because the production costs are very high..."

One strategy to revive newspapers through e-paper can be a means for newspapers to be published without relying on production costs because e-paper does not require paper. The strategy of placing e-paper and print bundling subscription packages is a special strategy to maintain print media for consumers who subscribe. However, challenges also arise from consumers who still have "..we used the e-paper subscription pattern, but do people still want to buy information? Actually, this is also a trial and error for several media such as Kompas and Tempo make a paywall, a digital subscription. However, they said the progress could not be expected because now people feel that information should be free..."

Currently, e-paper is still a supporter in the life of print media, but e-paper is not 
yet stable. E-paper users in Indonesia are not like other countries that are interested in buying premium information. "The advantage of e-paper is that pages can be easily added, marketing opportunities as well (insert ad pages). Some pages are marketing directed not only to fill out journalism content but also to be designed and adapted to the wishes of the institutions that want to advertise. This is a pattern that is still not well established. However, it turns out that several newspapers have also tried, such as Kompas, tempo because the quality of journalism can still be maintained with the paywall. Most free portals tend to get stuck in clickbait because they still have to consider Google Adsense," The dominance of Google's digital advertising and the practice of news aggregation by digital platform companies has been implemented by several mass media in the world. In Indonesia, Google has collaborated with several media to advertise news portals (Nugroho, 2021). Even with the culture and mindset of the people, Erwin argues that the middle class is antipathetic to clickbait news portals, but their interest in subscribing is not significant. "..look at the experience of the new york times, with the paywall system. Customers want to pay a subscription fee of 1 dollar, without production costs except for the digital online development server. No paper costs benefit the industry..."

The Pikiran Rakyat Newspaper is not doing well. Erwin even revealed that the current situation is very complicated in the midst of technological developments and changes in people's mindsets and culture in consuming dynamic information. Print media is no longer as powerful as it used to be. However, the editors still believe that the Pikiran Rakyat newspaper can survive with the right strategy, starting from e-paper, convergence, and information business strategies. Pikiran Rakyat finally focused on online programming systems with lower operating costs. The position of the Pikiran Rakyat newspaper is difficult to predict. Erwin acknowledged this because Pikiran Rakyat does not have large investment potential. Therefore, management's choice is the easiest and cheapest option. The limited sources of funds, especially for investment, have chosen Pikiran Rakyat Newspapers to survive not much. Then the journalistic system with programming will be the choice for now. However, this raises anxiety about the quality of the journalistic products produced. The quality of journalistic journalism is questioned because of the speed and amount of news per day that are the benchmarks for journalists" performance in reporting. "...the requirements for a reporter whose name also changes to content creator in the programmatic realm are different. For our journalists who are standard journalism, a journalist must go into the field, cover both sides, and so on. Well, if it is programmed, it is not. They are not even allowed to go to the field because they are being charged with dozens of news a day...."

Good reporting should incorporate the journalistic sides so that the news media creates its original frame for social events through the act of gathering information, reporting, and preparing news texts (Joyce, 2011). Anxiety was also experienced by field reporters at the Pikiran Rakyat Newspaper. One of the journalists, Rani Ummi Fadila, expressed her concern about the future of the print media where she works. Journalists in print media, according to him, are different from journalists in online media. Print media journalists can deepen the news, although not as fast as online media journalists. However, in a situation like this, the declining print media business made him think about adapting to become an online media journalist. The uncertainty of the fate of print media journalists has made the situation even more uncertain. Rani admitted that as a journalist, she wanted to continue to carry out actual journalistic activities in print media. However, she had no choice to start studying online 
journalists' reporting patterns and the risk that online journalists were contract freelancers. "...if there are other options in the online (media. But the Pikiran Rakyat has no other choice, and his status in online journalists is a contract employee, different from the print media with permanent employee status..."

The specialization of journalists in the Pikiran Rakyat newspaper is different. According to Rani, it can be used in reporting strategies without relying on computerization or news programming. This specialization can distinguish news in the Pikiran Rakyat from news in online media that relies only on speed. "...it does discriminate against journalists. So there are journalists who specialize in speed, journalists with in-depth news, and other journalists who specialize in narrative news. So there are specialties. Some are fast and of high quality..." Print media journalists are currently trying to rise up in the midst of digital society. Even so, print media journalists still do not want to leave the actual journalistic activities to compete with the speed of information.

Erwin responded to this problem by providing his views on the existence of print media, especially newspapers, in the digital information era. Print media is difficult to survive from an economic perspective. However, the press industry relies not only on the economic aspect but also on public trust and the quality of its news as its product. Print media can be an icon or branding product for loyal customers as a form of emotional and historical closeness. Readers of the Pikiran Rakyat newspaper can be segmented into readers of the digital information consumer society and loyal readers of scholars and community leaders who provide their ideas and ideas in newspapers. "...the newspaper still exists with the flagship model and is then integrated online. However, the risk is that it will automatically reduce its employees when integrated. The news ecosystem pattern with incubation input patterns is no longer organic. so there is no institutional attachment between the parent and the sub-domains." Print media is a media that has special characteristics that are different from other media. Although today's society prefers to consume information digitally, print media is still needed as a complete news item which is now difficult to find in the characteristics of online media that prioritizes the speed of information.

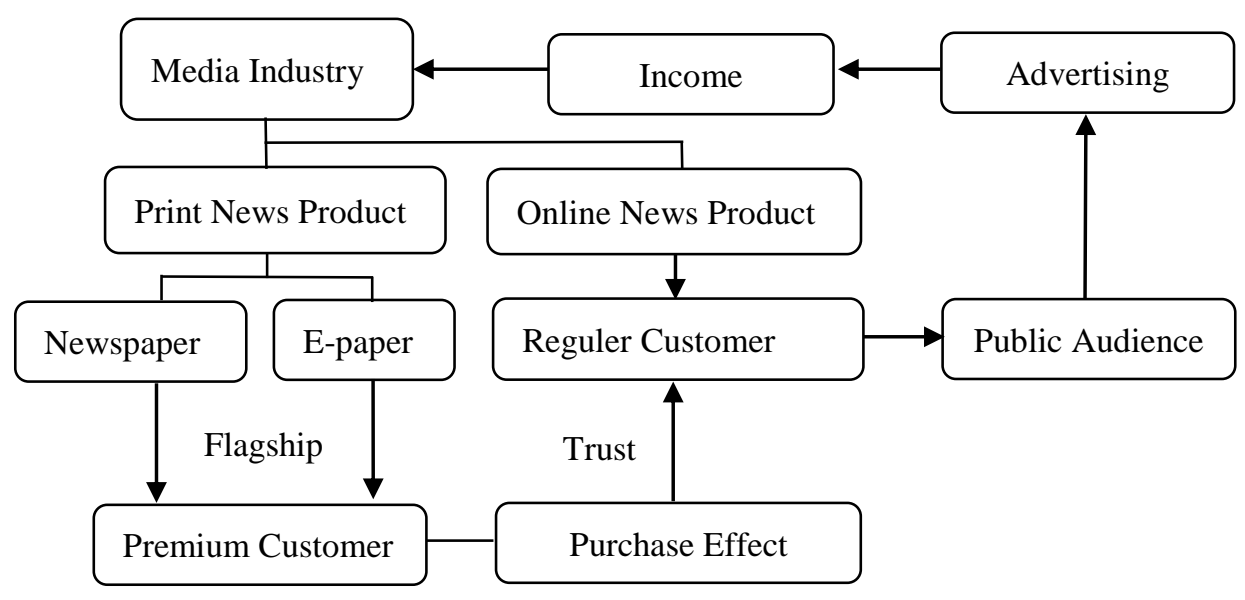

Figure 1. Print Media Flagship Model

The print media industry will not survive if it maintains the old ways of earning income. The print media industry can survive by collaborating with digital platforms as 
a source of income that can provide subsidies from advertising on digital platforms. However, the presence of print media as a flagship is also a consideration in influencing public trust in the media. Public trust in print media compared to online media can be a factor that strengthens public loyalty in consuming certain media. Print media can be a premium product only given to customers who are considered loyal. Loyal customers can be agents who positively influence others to consume information from the media. The strategy of print media as a flagship to gain public trust can become a business model for the print media industry in the future.

\section{Conclusion}

The study results produced several conclusions that can describe how print media can survive in the era of digital society. The conclusion on the quantitative data shows that the respondents' audience has begun to leave the pattern of consumption of information through print media and switch to the pattern of consumption of digital information, especially online media and social media. The pattern of public consumption in print media is very rare with buying newspapers through retail. However, among the print media, newspapers are still one of the print media consumed by the respondent's audience. The reason is that print media has several advantages over online media, namely the content of the news that is fact-tested and not clickbait. Impracticality, less attractive appearance, and prices that are not free make the audience leave the print media. For some respondents, the habit factor is the reason they still consume print media.

The shift in the pattern of information consumption in society, which shifts from print to digital, affects newspaper circulation sales. The figures from various circles who became informants in the FGD explained several points that need to be considered by the Pikiran Rakyat as a print media that still survives to this day. The Pikiran Rakyat newspaper needs to pay attention to the historical and geographical proximity factors that can become regional print media's values and characteristics. Some opinions state that the Pikiran Rakyat Newspaper needs to consider a more productive business strategy by considering millennial readers with different consumption patterns. Others believe that print media can survive in a special segmentation as a quality, in-depth, comprehensive, and trustworthy alternative media.

Based on the results of qualitative data, the editors of the Pikiran Rakyat Newspaper have taken several steps to survive at this time. However, some are doubtful whether it will work. The e-paper strategy, subscription newspaper package promos, and the paywall system are still deemed unable to save print media. In media economic theory (Picard, 2003), it is very difficult for print media to survive as the main source of income. However, the optimism that print media brings high-quality journalism requires print media to be maintained. The existence of print media can still survive, but not as a source of income but as an icon and branding in the media industry. Flagship as pride in a society with civilization makes print media necessary to survive while changing people's consumption patterns towards digital.

The opportunity for print media to be accepted and consumed by the public still exists, although it is minimal because of the changing consumption patterns of information. The public prefers accurate journalism to fast-paced journalism. The audience chooses to consume information that has news depth (but is concise), has emotional closeness, and can be trusted (not clickbait like online media). Problems also occur in the pattern of coverage of print media journalists who have to adapt to writing 
news in online media, which demands speed but is not as thorough as in print media. Even so, the relevance of the existence of print media in the era of digital information consumption needs to be further deepened because of the opportunity for print media to survive as an icon or flagship of media companies. The value in the news as reliable information is one of the advantages of print media that can be used as premium information to customers because the value in reliable information and news content is the core in news products. Then, the results of this research can be used as input for Pikiran Rakyat to implement strategies in maintaining the existence of print media, especially newspapers, amid a shift in public information consumption in the digital era. This research also encourages other studies that focus on media, new media, and changes to conventional media.

\section{Acknowledgements}

This research was fully funded by the Institute for Research and Community Service at the Universitas Islam Bandung (LPPM Unisba). The authors would also thank everyone involved and help in this research, especially the Editors and Management of the Pikiran Rakyat Newspaper, a partner in this research. We thank partners, respondents, and resource persons who have provided a lot of data, both primary data and supporting data.

\section{References}

Albarran, A. B. (1998). Media Economics: Research Paradigms, issues, and Contributions to Mass Communication Theory. Mass Communication <html_ent Glyph="@amp;" Ascii="\&amp;"/> Society, 1(3\&4), 117-129. https://doi.org/10.1207/s15327825mcs0103\&4_1

Altınba, F. (2016). The Impact of Print Media on Popular Culture: Umberto Eco's Number Zero. 1(1), 73-86.

Aminuddin, A. T., \& Hasfi, N. (2020). Konvergensi Media Surat Kabar Harian Lokal $\begin{array}{lllll}\text { Jateng Pos. Jurnal Kajian Jurnalisme, } & 37 .\end{array}$ https://doi.org/10.24198/jkj.v3i2.25070

Creswell, J. W. (2013). Qualitative Inquiry \& Research Design: Choosing Among Five Approaches. Sage.

Dewi, P. A. R. (2011). Konstruksi Identitas Kedaerahan oleh Media Massa Lokal. Jurnal ASPIKOM, 1(2), 149. https://doi.org/10.24329/aspikom.v1i2.14

Djamba, Y. K., \& Neuman, W. L. (2002). Social Research Methods: Qualitative and Quantitative Approaches. In Teaching Sociology (Vol. 30, Issue 3). https://doi.org/10.2307/3211488

Doyle, G. (2015). Multi-platform media and the miracle of the loaves and fishes. Journal of Media Business Studies, 12(1-2), 49-65. https://doi.org/10.1080/16522354.2015.1027113

Fazryansyah, M. I., Agustina, H., \& Nuruzzaman, N. (2014). Manajemen Redaksional Pada Surat Kabar Harian Umum Radar Cirebon (Studi Deskriptif Kualitatif Manajemen Redaksional pada Surat Kabar Harian Umum Radar Cirebon Periode $\begin{array}{lllll}\text { Januari-Mei 2013). Jurnal } & \text { ASPIKOM, }\end{array}$ https://doi.org/10.24329/aspikom.v2i2.62

Firmansyah, \& Asgha, A. Y. (2020). Journalist' s Information Organizational Patterns in Reporting Indonesian Vice President' s Agenda Pola Organisasi Informasi Wartawan Dalam Meliput Agenda Wakil Presiden Indonesia. 5(2), 307-321. 
Hasni, N., Cangara, H., \& Fatimah, J. M. (2019). Daya Tahan Bisnis Media Cetak Ditengah Maraknya Penggunaan Media Online Di Kota Makassar ( Skh Fajar Dan Skh Tribun Timur ) Media of Impresion of Business Resistance in the Middle of the Use of the Media in Line of the City of Makassar (Fajar and Skh Skh. II(I), 43.

John Creswell. (2009). Research Design: Qualitative, Quantitative, and Mixed Methods Approach. In Intercultural Education (Issue 2). SAGE Publications. https://doi.org/10.1080/14675980902922143

Joyce, V. de M. H. (2011). Transnational News Media Role in Building Consensus about Communities. 4(2), 111.

Karambelkar, M. N. (2019). IMPACT OF DIGITAL MEDIA ON PRINT MEDIA. 16091614.

Kurnia, S. S., Kuswarno, E., Maryani, E., \& Firmansyah. (2021). The characteristics of investigative news organizations in Indonesia between 2010-2012. Heliyon, 7(2). https://doi.org/10.1016/j.heliyon.2021.e06276

Kusuma, S. (2016). Posisi Media Cetak di Tengah Perkembangan Media Online di Indonesia. Unika Atma Jaya, 5, 56-71.

Leksmana, A., Mayasari, \& Poerana, A. F. (2020). Geliat Konvergensi Media Cetak Lokal. Commed : Jurnal Komunikasi Dan Media, 5(1), 15-33.

Marchi, R. (2012). With Facebook, blogs, and fake news, teens reject journalistic "objectivity." Journal of Communication Inquiry, 36(3), 246-262. https://doi.org/10.1177/0196859912458700

McKenney, M. (2018). Digital transformation in journalism and news media: media management, media convergence and globalization. In International Journal on Media Management 20(2). https://doi.org/10.1080/14241277.2018.1484623

McQuail, D. (2010). McQuail's Mass Communication Theory (6th ed.). SAGE Publications Ltd. http://docshare04.docshare.tips/files/28943/289430369.pdf

Nugroho, I. (2021). The Dynamics of Mass Media Resistance toward Google. Jurnal ASPIKOM, 6(2), 278. https://doi.org/10.24329/aspikom.v6i2.856

Nurliah. (2018). Konvergensi dan Kompetisi Media Massa dalam Memenangkan Pasar di Era Media Digital di Maka. Journal Tabligh, 19(1), 106-11b.

Othman, S. S., Hassan, F., Sabri, S. A., \& Nayan, L. M. (2020). Fake News from The Islamic Perspective. MIMBAR: Jurnal Sosial Dan Pembangunan, 36(1), 159168. https://doi.org/10.29313/mimbar.v36i1.5467

Picard, R. G. (2003). Media economics. In A Handbook of Cultural Economics. https://doi.org/10.4337/9781781008003.00045

Purnamasari, N. I. (2018). Resepsi Pembaca terkait Berita Demo 4/11 di Kompas.com. Jurnal ASPIKOM, 3(5), 958. https://doi.org/10.24329/aspikom.v3i5.358

Rampersad, G., \& Althiyabi, T. (2020). Fake news: Acceptance by demographics and culture on social media. Journal of Information Technology and Politics, 17(1), 1-11. https://doi.org/10.1080/19331681.2019.1686676

Restendy, M. S. (2020). Dinamika Produksi Media Cetak Dan Tantangan Industri Pers Di Indonesia. Jurnal Komunikasi Dan Penyiaran Ilslam, 1(2), 141-164.

Saragih, M. Y., \& Harahap, A. I. (2020). The Challenges of Print Media Journalism in the Digital Era. Budapest International Research and Critics Institute (BIRCIJournal): Humanities and Social Sciences, 3(1), 540-548. https://doi.org/10.33258/birci.v3i1.805

Smits, T. (2014). Problems and possibilities of digital newspaper and periodical 
$\begin{array}{lllll}\text { archives. } & \text { Tijdschrift Voor } & \text { Tijdschriftstudies, } & \text { O(36), } & 139 .\end{array}$ https://doi.org/10.18352/ts.317

Subudhi, R. N. (2021). Digital consumption pattern and impacts of social media: Descriptive statistical analysis. In Studies in Computational Intelligence (Vol. 954, Issue March). Springer Singapore. https://doi.org/10.1007/978-981-33-68156_3

Supadiyanto, S. (2020). (Opportunities) Death of Newspaper Industry in Digital Age and Covid-19 Pandemic. Jurnal The Messenger, 12(2), 192. https://doi.org/10.26623/themessenger.v12i2.2244

Tim Pikiran Rakyat. (2019). Sejarah Pikiran Rakyat Sejak 1967. https://www.pikiranrakyat.com/bandung-raya/2019/03/24/sejarah-pikiran-rakyat-sejak-1966

Vidas-Bubanja, M., \& Bubanja, I. (2015). Competitive management strategy for print media advertising activities. Journal of Engineering Management and Competitiveness, 5(2), 68-76. https://doi.org/10.5937/jemc1502068v

Zickuhr, K., \& Madden, M. (2012). Older adults and internet use. Pew Reseach Center's Internet \& American Life Project, 114(1), 38-41. https://doi.org/10.1177/135910539600100304 